\title{
TECHNIQUES FOR IMPROVING THE STRENGTH AND FITNESS OF SPINAL INJURED PATIENTS
}

\author{
By J. C. Chawla, M.D., F.R.C.S., C. Bar, M.Sc., I. Creber, M.C.S.P., J. Price, \\ M.R.S.G. and B. ANDREWS, M.Sc. \\ Rookwood Hospital, Cardiff, Wales
}

\begin{abstract}
Physiological data on athletes and animals has been used to design this training programme and to suggest new perspectives for training the spinal cord injured. The training routines proposed are designed to improve endurance and strength and modern weight training equipment has been modified for this purpose.
\end{abstract}

Key words: Strength; Fitness of spinal injured patients.

\section{Introduction}

THE degree of the independence in daily living of the spinal cord-injured patients, not only depends upon the prevention of complications, but also on their physical fitness. The accepted components of the physical fitness may include muscle strength, endurance, neuromuscular coordination and efficient cardio-respiratory systems. These are achieved by compensatory training of those innervated muscles which are important for balance, mobility of the trunk, maintenance of upright posture, adequate ventilation and the abdominals for reconditioning of the bladder.

The patients will tend to vary much in their capabilities according to their age, level of injury and the degree of cord damage, whether complete or incomplete.

Muscle strength may be defined as the tension which a muscle can develop in an attempt to overcome an imposed load, either in lifting a weight (isototonic) or during a static (isometric) contraction against a fixed resistance; whereas endurance is the ability of a muscle to perform repetitive contractions which are dependent on cardio-respiratory efficiency.

Two types of muscle fibre, red and white, have been identified histologically. The white fibres are designed for rapid, powerful contractions of infrequent occurrence because they have limited blood supply and very few mitochondria and thus have to rely mainly on anaerobic metabolism (glycolisis) for energy. A strength training stimulus results in a thickening and an increase in the number of myofibrils, particularly in white fibres (Gordon, 1976). Training with weights which can be lifted one to six times with maximum effort (high load and low repetitions) is the most effective stimulus. The repetitions are few and the anaerobic pathways are adequate to supply energy. The aerobic pathway is slight. Compared to the white fibres, the red fibres are suited to slow frequent contractions of an enduring nature due to the rich blood supply and the high concentration of mitochondria (Henneman and Olsen, 1965). The endurance training stimulus results in increases in muscle mitochondria, energy liberating enzymes in the sarcoplasm and electron transport capacity (Faulkner I968, Herbison, I973).

To effectively increase strength and endurance, the muscles have to be overloaded. The theory of over load states that for a muscle to increase in size or functional ability, it must be taxed to the limit of its present ability to respond (Faulkner, I968). 
Weight training methods to improve the physical ability of spinal cord injured patients appear to be empirically controlled rather than scientifically based. In this Paper appropriate published data on athletes and animals has been used to suggest a weight training programme.

\section{Materials and Methods}

The equipment (Fig. I) is commercially available. However, the bench has been modified (Fig. 2) because the standard commercial multi-purpose benches for the normal population are unsuitable for spinal cord injured patients since they are too narrow, short and inadequately padded. The bench surface, which has been lengthened and shaped, consists of $\frac{3}{4}$-inch ply padded with 2 -inch vinyl covered foam. The narrow end supports the head and shoulders to allow freedom of movement. The wide part of the bench supports the body below the level of the shoulders to provide stability and support. All surface edges and other potentially dangerous protruberances are padded for safety and the prevention of pressure sores. The base of the bench has been widened for stability during transfers and exercises. Belts are provided to prevent sliding and to increase lateral stability. The wall pulley was designed to have an overhang positioned centrally over the bench and to provide sufficient space between it and the wall during exercise. The pulley bar is wide and curved at the extremities to allow fuller ranges of movement during back exercises. This system allows the patient to remain positioned on the bench throughout the training session.

When their spinal column is considered stable, patients start this programme

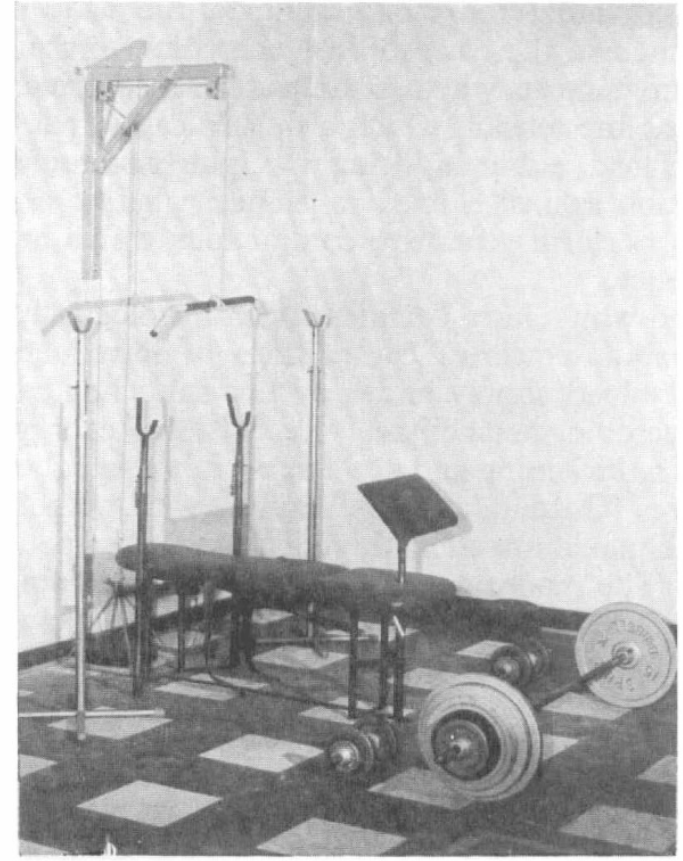

FIG. I

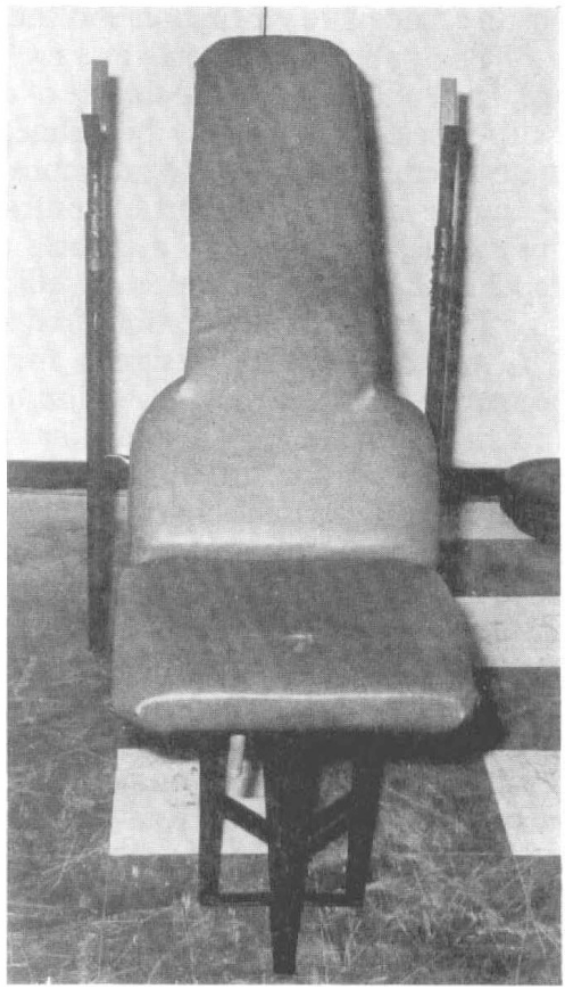

Modified Bench. 
TABLE I

Schedule of exercises

\begin{tabular}{lll}
\hline \multicolumn{1}{c}{ Exercises } & Sets $\times$ Repetitions \\
\hline I & Barbell bench press & I $\times 15$ warm up \\
2 & Barbell incline press $\left(60^{\circ}\right)$ & $3 \times 6$ \\
3 & Lateral raise with dumbells & $3 \times 6$ \\
4 & Incline curls with dumbells & $3 \times 6$ \\
5 & Pull down to back of neck with a wide grip & $3 \times 6$ \\
6 & Pull to the chest with a wide grip & $3 \times 6$ \\
7 & Lying barbell triceps stretch & $3 \times 6$ \\
8 & Straight arm pull-over with a swingbell & $2 \times 30$ \\
\hline
\end{tabular}

and their cardiovascular efficiency is assessed by monitoring pulse rate and ECG, before and during the training. Ten patients have completed this programme and no adverse effects have been observed. All have reported that activities of daily living are facilitated by the training.

\section{The Training Programme}

The programme involves three Phases. In Phase I the patient lifts a poundage which allows twenty repetitions to be performed with ease, so that the patient develops neuro-muscular coordination for each of the scheduled exercises (Table I). The patients enter Phase 2 when the therapist is satisfied with their progress. No hard and fast rules can be laid down because of the patients' response to the exercises in Phase I.

Phase 2 is designed to develop strength and endurance. The strength training is provided by a gradual increase in poundage and decrease in number of repetitions. The patient performs the exercises shown in Table I. The effects of various exercises on different groups of muscles are shown in Table II.

Supervision is essential during the performance of these exercises to ensure that weights are being lifted safely and correctly. The poundage is increased as soon as the patient can perform the prescribed number of repetitions easily. During training, a rest is taken in between sets to allow the heart rate and respiration to return to normal.

The endurance routine is designed to improve cario-respiratory efficiency and local muscle endurance. This type of training is used by athletes and is known as Peripheral Heart Action. Exercises for different muscle groups are selected and are arranged so that no two consecurive exercises involve the same prime movers. These are performed in rotation with as little rest as possible between each exercise. A moderate number of repetitions (i.e. fifteen) are employed for each exercise and the poundage is heavy enough to allow only the selected number of repetitions to be completed.

Table II illustrates a typical example of the schedule of exercises performed by a patient. This cycle of exercises is gradually increased as the patient progresses. On completion of each cycle, there is a rest period to enable the heart and respiratory rate to return to resting levels.

An example of a schedule is shown in Table III. 
TABLE II

\begin{tabular}{|c|c|c|}
\hline Exercise & Prime Movers & Comments \\
\hline $\mathbf{I}$ & $\begin{array}{l}\text { Pectoralii } \\
\text { Deltoids } \\
\text { Triceps }\end{array}$ & $\begin{array}{l}\text { The pectoralis major and anterior deltoid are } \\
\text { employed strongly as the bar is moved from the } \\
\text { chest. The triceps take over much of the effort in } \\
\text { the final few inches to lock-out. }\end{array}$ \\
\hline 2 & $\begin{array}{l}\text { Pectoralis minor } \\
\text { Deltoids } \\
\text { Triceps }\end{array}$ & $\begin{array}{l}\text { The anterior deltoid with help from the pectoralis } \\
\text { minor are strongly involved as the bar is pressed } \\
\text { from the shoulders. The lock-out involves the } \\
\text { triceps more strongly. }\end{array}$ \\
\hline 3 & $\begin{array}{l}\text { Deltoids } \\
\text { Trapezius }\end{array}$ & $\begin{array}{l}\text { A fine localised shoulder exercise affecting mainly } \\
\text { the lateral head of the deltoid. The trapezius also } \\
\text { works strongly as a fixator. }\end{array}$ \\
\hline 4 & $\begin{array}{l}\text { Biceps } \\
\text { Brachialis }\end{array}$ & \\
\hline 5 & Latissimus Dorsi & $\begin{array}{l}\text { Although the latissimus are the prime movers, the } \\
\text { other upper back muscles (i.e. trapezius, teres, } \\
\text { posterior deltoid, infraspinatus) are strongly in- } \\
\text { volved. The biceps are also strongly employed, } \\
\text { especially at the beginning of the pull. }\end{array}$ \\
\hline 6 & $\begin{array}{l}\text { Torso, Deltoid } \\
\text { Trapezius, } \\
\text { Latissimus Dorsi } \\
\text { Infraspinatus }\end{array}$ & $\begin{array}{l}\text { The prime movers are the posterior deltoid, teres } \\
\text { major and minor, infraspinatus and trapezius. } \\
\text { The latissimus are also strongly employed and a } \\
\text { lot of work is placed on the biceps at the beginning } \\
\text { of the pulling movement. }\end{array}$ \\
\hline $\begin{array}{l}7 \\
8\end{array}$ & $\begin{array}{l}\text { Triceps } \\
\text { Triceps } \\
\text { Latissimus } \\
\text { Pectoralii } \\
\text { Abdominals }\end{array}$ & $\begin{array}{l}\text { A stretching exercise for the triceps, latissimus, } \\
\text { pectoralii and abdominals. This exercise helps to } \\
\text { increase rib box size and is a valuable stretching } \\
\text { exercise for the upper body. Inhales as deeply as } \\
\text { possible as the bar is lowered backwards towards } \\
\text { the floor; exhales as the bar is pulled to the starting } \\
\text { position. }\end{array}$ \\
\hline
\end{tabular}

TABLE III

$\begin{array}{lll}\text { I } & \text { Incline Press } & \times 15 \\ 2 & \text { Pull to back of neck } & \times 15 \\ 3 & \text { Lateral raises } & \times 15 \\ 4 & \text { Incline curls } & \times 15 \\ 5 & \text { Tricep pushdowns } & \times 15 \\ 6 & \text { Straight arm pulley pullovers } & \times 25\end{array}$

This schedule is developed gradually and the number of cycles increased as the patient progresses; as many as five cycles can be performed. When a cycle has been completed a rest is taken to allow breathing and heart rate to return to resting levels but rest between individual exercises is as short as possible because the aim is to create maximum oxygen demand.

Only patients who wish to continue training after discharge and want to undertake some specific training for a particular activity or sport enter Phase 3. Specific fitness may be imposed on the basic fitness developed during Phase 2. 


\section{Discussion}

In the department of physical therapy, many techniques are available to improve stength and endurance. The most commonly used are: manual resistance (PNF), body resistance, spring and suspension therapy, weights and pulleys and sport.

In the manual resistance exercises, the therapist applies the resistance, but this may become less than is required for overload as the patient achieves elevated stength levels. The limiting factors in this technique seem to be a lack of control over the degree of resistance applied, but it seems to have an important role in the management of incomplete lesions.

The use of body weight to provide resistance, places a static level. Furthermore, it is not possible to graduate the resistance and the range of movements appear to be limited to dips and push-ups for the spinal cord injured patient. These exercises influence predominantly the adductor group of muscles. We feel that this leads to a restricted range of movement in elevation through flexion because antagonistic muscles are not being strengthened. The pulleys with weights appear to offer similar disadvantages. The springs offer certain disadvantages because the resistance increases as the movement proceeds, and the muscle is less able to overcome the resistance.

We feel that our programme offers advantages over the generally accepted techniques as it allows development of muscles through their full range of movement. The resistance can be graduated so that the optimum poundage can be achieved to ensure progressive muscle overload.

The pullover and lateral raises (Table I) have been beneficial for improving the lack of full range of movement in elevation through flexion. It has also been observed that posture faults have improved through strengthening of the upper back muslces. Flexor spasms occur in some patients due to abdominal stretch in some exercise positions. However, as the training session progresses, the spasms tend to ease considerably. The legs are strapped down to the bench if these are severe.

An approach to the training of patients with an awareness of the mechanisms of training at the cellular level and the hypothesis of overload, can make training more rewarding for the patient and more challenging for the therapist.

\section{RÉSUMÉ}

On a employé des donneés physiologiques an sujet des athlétes et des animaux, pour préparer cette programme d'instruction et pour suggérer des nouvelles perspectives pour l'instruction des personnes blessées au cordon médullaire. Le but de cette course d'instruction proposée est l'amelioration d'endurance et de force, et on a modifié l'equipement moderne pour l'entrainement, en faisant de l'alterophilie, à cet effet.

\section{ZUSAMMENFASSUNG}

Physiologische Daten von Athleten und Tieren wurden angewandt, um dieses Ausbildungsprogram zu planen, und neue Perspektiven der Ausbildung der Patienten mit Rückenmarkbeschädigung vorzuschlagen. Die vorgeschlagenen Ausbildungsroutinen werden geplant, Ausdauer und Stärke zu verbessern, und moderne Ausrüstung des Gewichthebens wurde zu diesem Zweck modifiziert.

\section{REFERENCES}

FAULKNER, J. A. (1968). Fama, 205, I I 7-I22.

GORDON, E. E. (1967). Fama 201, 755-758.

HENNEMAN, E. \& OlsEN, C. B. (I965). Ұ. Neurophysiol 28, 58I-598.

Herbison, G. J. \& Gordon, E. E. (I973). Arch. Phys. Med. Rehab. 54, 409-4I5. 